\title{
Yüksek Tansiyon Tedavisinde Kullanılan Bazı İlaç Etken Maddelerinin UV/VIS Spektrofotometrik ve Yüksek Basınçlı Sıvı Kromatografik (HPLC) Yöntemlerle İncelenmesi ve Elde Edilen Verilerin Kemometrik Yöntemlerle Değerlendirilmesi
}

\author{
A. Hakan AKTAȘ ${ }^{1}$, Uğur YAVAŞ*2 \\ 1,2Süleyman Demirel Üniversitesi, Fen-Edebiyat Fakültesi, Kimya Bölümü, 32260, Isparta, Türkiye \\ ${ }^{1}$ (ORCID: https://orcid.org/0000-0003-2327-4031) \\ ${ }^{2}$ (ORCID: https://orcid.org/0000-0003-1046-0142)
}

(Alınıș / Received: 02.11.2018, Kabul / Accepted: 04.03.2019, Online Yayınlanma / Published Online: 24.04.2019)

Anahtar Kelimeler

HPLC,

UV/VIS,

Kemometri,

Kinapril,

Hidroklorotiyazid, PCA
Özet: Son yıllarda hipertansiyon tedavisinde kullanılan ilaçların etken maddelerini tayin etmek amacıyla çeşitli yöntemler geliştirilmektedir. Çalışmada, ilaç etken maddelerinden kinapril ve hidroklorotiyazid, UV/VIS ve HPLC yöntemlerle incelendikten sonra sonuçlar kemometrik yöntemlerden PLS ve temel PCR ile değerlendirilerek analizlerin doğruluk ve kesinlik açısından desteklenmesi sağlanmıştır. UV/VIS çalışmalarından sonra, kinapril ve hidroklorotiyazidin PCR analizleri sonucu geri kazanım değerleri sırasıyla $\% 100,56$ ve $\% 99,85$; standard saplamalar ise 0,512 ve 0,027 ; PLS çalışmaları sonucu geri kazanım değerleri sirasiyla $\% 99,18$ ve $\% 99,75$; standard saplamalar ise 0,334 ve 0,289 olarak hesaplanmıștır. HPLC çalıșmalarından sonra, kinapril ve hidroklorotiyazidin PCR analizleri sonucu geri kazanım değerleri sırasıyla \%100,01 ve \% 99,78; standard saplamalar ise 0,170 ve 0,241 ; PLS çalışmaları sonucu geri kazanım değerleri sirasiyla $\% 100,57$ ve $\% 100,51$; standard saplamalar ise 0,462 ve 0,706 olarak bulunmuştur. Çalışmada UV/VIS ve HPLC yöntemlerinin ilaç etken maddelerinin eş zamanlı tayinindeki yeterlilikleri kemometrik olarak incelenmiş olup çıan sonuçlar doğrultusunda bu yöntemlerin kinapril ve hidroklorotiyazid'den oluşan hipertansiyon ilaçlarının kalitesi ve hedefe uygunluğu ile ilgili çalışmalarda kullanılabilirliğinin olduğu sonucuna varılmıștır.

\section{Investigation of Some Drugs Used in High Blood Pressure Treatment by UV/VIS Spectrophotometric and High Pressure Liquid Chromatographic (HPLC) Methods and Evaluation of Obtained Data by Chemometric Methods}

Keywords

HPLC,

UV/VIS,

Chemometry,

Quinapril,

Hydrochlorothiazide, PCA

\begin{abstract}
Various methods have been developed in recent years to determine the active ingredients of drugs used in the treatment of hypertension. In this study, active agents such as quinapril and hydrochlorothiazide were examined with UV/VIS and HPLC methods and to ensure accuracy and precision, studies are supported by PLS and PCR chemometric analyzes. After UV / VIS studies, recovery values of quinapril and hydrochlorothiazide as a result of PCR analysis were $100.56 \%$ and $99.85 \%$, respectively; standard deviations are 0.512 and 0.027 ; As a result of PLS analysis, recovery values were $99.18 \%$ and $99.75 \%$, respectively; and the standard deviations were calculated as 0.334 and 0.289 . After HPLC studies, the recovery values of quinapril and hydrochlorothiazide as a result of PCR analysis were $100.01 \%$ and $99.78 \%$, respectively; the standard deviations are 0.170 and 0.241 ; As a result of PLS studies, recovery values were $100.57 \%$ and $100.51 \%$, respectively; and the standard deviations were found to be 0.462 and 0.706. In this study, the efficacy of UV/VIS and HPLC methods in the simultaneous determination of the drug active substances were examined chemometrically and it is concluded that these methods can be used in studies related to the quality and target suitability of hypertension drugs composed of quinapril and hydrochlorothiazide.
\end{abstract}




\section{Giriş}

Kalp ve damar hastalıklarının tedavisinde kullanılan ilaç grupları; $\alpha$ (reseptörlerin) almaç engellemesi ( $\alpha$ blockers), $\beta$ reseptörlerin engellenmesi ( $\beta$ blockers), kalsiyum kanallarının engellenmesi veya antijotensin dönüştürücü enzim aktivitelerinin engellenmesi şeklinde etki göstermektedir. Kan basıncının düzenlenmesinde ACE inhibitörleri büyük bir role sahibidir. Bu tür ilaç grupları kan damarlarını genişleterek ve vücuttaki fazla suyun atılmasını sağlayarak damarlardaki basıncı azaltır [1-4].

Kinapril hidroklorür [(3S) -2 - [(2S) -2 - [[((2S) -1etoksi-1-okso-4-fenilbütan-2-il] amino] propanoil] 3,4-dihidro-1H-izokinolin-3 -karboksilik asit; hidroklorür] hipertansiyon ve kalp yetmezliğinin tedavisinde kullanılan ACE inhibitörlerindendir (Şekil 1) [5].<smiles>CCOC(=O)[C@H](CCc1ccccc1)N[C@@H](C)C(=O)N1Cc2ccccc2C[C@H]1C(=O)O</smiles>
$\mathrm{HCl}$

Şekil 1. Kinapril hidroklorür [5]

Hidroklorotiyazid [6-kloro-1,1-diokso-3,4-dihidro$2 \mathrm{H}-1 \lambda 6,2,4$-benzotiadiazin-7-sülfonamid] (HCT) ise hipertansiyonun tedavisinde etkili olan bir antihipertansif diüretik ajandır (Şekil 2) [5-6].<smiles>NS(=O)(=O)c1cc2c(cc1Cl)NCNS2(=O)=O</smiles>

Şekil 2. Hidroklorotiyazid [5]

ACCUZIDE ${ }^{\circledR}$ FORT yüksek kan basıncının tedavisi için kullanılan, bu iki etken maddeyi içeren bir ilaçtır. Her bir film tablet, $20 \mathrm{mg}$ kinaprile eşdeğer kinapril hidroklorür ve $25 \mathrm{mg}$ hidroklorotiyazid içeren 30 tabletlik blister ambalajlarda kullanıma sunulmuştur. ACCUZIDE ${ }^{\circledR}$ FORT pembe, üçgen, bikonveks, film kaplı tablettir.

Yüksek tansiyon tedavisinde tek bir etken madde içeren ilaç ile tedavinin yetersiz olduğu durumlarda bu iki etken madde birlikte kullanılmaktadır. Hidroklorotiyazid vücuttan atılan idrar miktarını artırarak kan basıncının azalmasını sağlarken kinapril ile kombinasyonu antihipertansif etkileri artırir.

Hipertansiyon tedavisinde bu iki bileşiğin kombinasyonu son yıllarda popülerleștiğinden aynı anda tespiti için daha hızlı ve duyarlı analiz yöntemleri geliştirilmek üzere çeşitli çalışmalar yapılmıştır. Bileşik dozaj formundaki kinapril ve hidroklorotiyazidin etken maddelerinin eş zamanlı tayini için yapılan çalışmada yüksek performans sıvı kromatografisi (HPLC) yöntemi geliştirilmiştir. Foto diyot dizisi dedektörü kullanılarak gerçekleştirilen analizde $220 \mathrm{~nm}$ 'deki dalga boyu kullanılmıştır. İstatistiksel analizler sonucunda geliştirilen kromatografik yöntemin ilaç içeriğini belirlemede başarılı olduğu bildirilmiştir [7]. Aynı etken maddelerin eş zamanlı tayininin yapıldığı bir başka çalışmada ise ters faz HPLC yöntemi uygulanmıştır. İç standart kullanılarak gerçekleştirilen çalışmada UV görünür bölge dedektörü 211 nm'ye ayarlanmıştır. Validasyonu gerçekleștirilen yöntemin sentetik karışımlarda ve farmasötik dozaj formlarındaki kinapril ve hidroklorotiozidin tayininde başarıyla kullanılabileceği görülmüștür [8]. Yöntem geliştirmek amacıyla yapılan bir başka çalışmada ise üç farklı analitik yaklaşım kullanılmıştır. Bu çalışmada, ilaçlar sirasıyla UV/VIS ve FT-IR spektrofotometre kullanılarak çift dalga boyu yöntemi ve kalibrasyon eğrisi yöntemleri ile analizleri yapılmıștır. Daha sonra HPLC kullanılarak yöntemin kararlılığı değerlendirilmiștir [6].

$\mathrm{Bu}$ çalışmanın temel amacl, kinapril hidroklorür ve hidroklorotiyazid etken maddelerinin eş zamanlı tayininde uygulanan yöntemlerin uygunluğunun kemometri ile değerlendirilmesidir. Bu amaçla, ilaç etken maddelerinin tayini UV/VIS ve ters faz HPLC yöntemleri ile gerçekleştirilmiş ve elde edilen veriler kemometrik kalibrasyon yöntemlerinden temel bileşen regresyon yöntemi (PCR) ve kısmi en küçük kareler yöntemi (PLS) uygulanarak analiz edilmiştir. Kemometrik hesaplamalardan önce temel bileșen analizi (PCA) uygulanmıştır.

Her iki analiz yöntemi sonucunda PLS ve PCR ile \% geri kazanımlar ve standart sapmalar hesaplanmıştır. Elde edilen sonuçlara istatistiksel olarak F-testi uygulanmıștır. Sonuçlar kıyaslanarak farklılığın anlamlı olup olmadığına bakılmıștır. $\mathrm{Bu}$ sayede çalışılan yöntemlerin hassasiyet, doğruluk ve seçicilik bakımından desteklenmesi sağlanmıştır.

\section{Materyal ve Metot}

$\mathrm{Bu}$ çalışmada, mor ötesi ve görünür bölge (UV/VIS) spektrofotometrisi ve yüksek basınçlı sıvı kromatografisi (HPLC) ile kinapril ve hidroklorotiyazid adlı ilaç etken maddelerinin nicel analizi yapılmıștır. Her iki analiz yöntemi sonucunda da elde edilen veriler ayrı ayrı, temel bileşen analizi yöntemi (PCA), temel bileşen regresyon yöntemi (PCR) ve kısmi en küçük kareler yöntemi (PLS) gibi kemometrik yöntemlerle değerlendirilmiştir.

Kinapril (KIN) ve hidroklorotiyazid (HCT) etken maddelerinin spektrumları ilk adımda ayrı ayrı 
çözeltiler hazırlanarak, daha sonra ise ikili karışımlar halinde setler hazırlanarak okumuştur. Son olarak ilaç örneğinin çözeltisi hazırlanarak ölçümler yapılmıştır. Tüm bu analiz sonuçları istatistik programıyla değerlendirilmiştir.

\subsection{Kullanılan kimyasallar}

UV/VIS ve HPLC analizlerinde kullanılan kinapril (Sigma Aldrich) ve hidroklorotiyazid (Sigma Aldrich) etken maddeleri analitik saflıkta kullanılmıștır. Bu nedenle etken maddelere tekrar saflaştırma işlemi yapılmasına gerek kalmamıştır. Analizlerde mobil faz hazırlamada kullanılan asetonitril (Sigma Aldrich) ise HPLC saflıkta tercih edilmiştir.

HPLC çalışmalarında iç standart olarak donepezil (Sigma Aldrich) seçilmiştir. $100 \mathrm{~mL}$ mobil faz hazırlamak için asetonitril ve su (35:65 v/v) kullanılmıștır. Karıșıma $30 \times 10^{-3} \mathrm{M}(30 \mathrm{mM})$ ortofosforik asit $\left(\mathrm{H}_{3} \mathrm{PO}_{4}\right.$, Sigma Aldrich) eklenmiş ve suda hazırlanmıș sodyum hidroksit ( $\mathrm{NaOH}$, Sigma Aldrich ) çözeltisi ile mobil fazın $\mathrm{pH}$ değeri istenilen çalışma değerine getirilmiştir. Mobil faz ultrasonik karıștırıcıda degaze edildikten sonra kullanılmıştır. UV/VIS analizlerinde hazırlanan tüm çözeltilerde çözücü olarak HPLC analizlerinde kullanılan mobil faz kullanılmıştır.

Kinapril (KIN) ve hidroklorotiyazid (HCT) maddeleri ile 100 ppm'lik stok çözeltiler hazırlanmıştır. Daha sonra bu stok çözeltiler kullanılarak istenilen derişim aralığına seyreltilerek kalibrasyon ve validasyon setleri oluşturulmuştur.

Kinapril ve hidroklorotiyazid etken maddelerini bir arada bulunduran ACCUZIDE ${ }^{\circledR}$ FORT'un (Pfizer) miktar tayini için hem HPLC hem de UV/VIS yöntemi için; ACCUZIDE ${ }^{\circledR}$ FORT'tan 10 adet tablet tartılmış ve havanda iyice toz haline getirilmiştir. $20 \mathrm{mg}$ kinaprile eşdeğer miktarda toz karıșım alınmış ve mobil faz ile 100 mL'ye seyreltilmiştir. Çözünmenin tam sağlanabilmesi için en az iki saat manyetik karıştırıcıda karıştırılmıştır. Daha sonra çözelti mavi bant süzgeç kağıdından süzülmüş ve süzüntü kalibrasyon derişim aralığına gelene kadar seyreltilmiştir. Hazırlanan çözeltilerin renksiz olduğu görülmüştür.

\subsection{Kullanılan cihazlar ve programlar}

UV/VIS analizleri UV 1700 PHARMASPEC SHIMADZU (Shimadzu, Kyoto, Japan) spektrofotometresi ile yapılmıștır. Spektrumlar cihaza ait olan güncel software yardımıyla bilgisayar ortamında okunmuş ve veriler Excel ile işlenerek grafik haline getirilmiştir. Cihazda absorbans ölçümlerinde iki adet şeffaf kuartz küvet kullanılmıştır. HPLC analizlerinde Purospher ${ }^{\circledR}$ STAR RP-18 Endcapped HPLC Kolonu, Diode Array Dedektörü SPD-M20A kullanılmıştır.
HPLC ve UV/VIS analizleri sonucunda elde edilen verileri PCA, PCR ve PLS gibi kemometrik yöntemlerle değerlendirme için Minitab 18 programı kullanılmıştır. Çalışmalarda kullanılan kimyasal maddelerin açık formülleri ChemDraw Professional 16.0 programı ile çizilmiştir. ANOVA testleri Microsoft ${ }^{\circledR}$ Office 2016'nın Excel programı ile yapılmıştır.

\subsection{Yöntem}

Saf kinapril ve hidroklorotiyazid etken maddelerinin stok çözeltilerinden yola çlkarak çeşitli derişimlerde (kinapril için 4-20 ppm, hidroklorotiyazid için ise 525 ppm arası) 25 mL'lik çözeltiler hazırlanmış ve bunların spektrumları okunmuştur. Her iki etken maddenin maksimum absorbans verdiği dalga boyu farklı olduğu görülmüștür. Bu nedenle herhangi bir ayırma işlemine gerek duyulmadan, her iki maddenin de belli derişimlerde karıştırılması sonucu oluşturulan çözeltilerin absorbans okumaları yapılmıştır.

En son aşamada ise iki etken maddeyi de içeren ACCUZIDE ${ }^{\circledR}$ FORT ilacından yola çıkarak hazırlanan çözeltilerin absorbans değerleri okunmuştur.

HPLC analizlerinde ilaç etken maddelerinin hazırlanan stok çözeltilerinin kromatogramları okunmuştur. Daha sonra stok çözeltilerden yola çıkarak kinapril ve hidroklorotiyazid için ayrı ayrı derişimlerde çözeltiler hazırlanmış ve bunların karışımı ile kalibrasyon ve validasyon setleri oluşturulmuştur. Oluşturulan bu setlerin teker teker kromatogramları okunmuştur.

Çalışma boyunca HPLC koşulları, izokratik programda, akış hızı 1ml/dakika, enjeksiyon hacmi $20 \mu \mathrm{L}$ ve kolon sıcaklığ $25^{\circ} \mathrm{C}$ olarak ayarlanmıștır. HPLC'den elde edilen verilerin kemometrik analizde kullanılmasında, maddelerin pik alanlarının iç standardın pik alanına oranları kullanılmıștır. Bu işlem altı farklı dalga boyunda $(210,215,220,225$, 230 ve $235 \mathrm{~nm}$ ) yapılmıştır.

Son basamakta ise, piyasada satılan ilaç numunesindeki ilaç etken maddelerinin çözeltileri incelenmiştir. Elde edilen veriler, farklı kemometrik yöntemlerle değerlendirilmiştir.

Kemometrik değerlendirmelerde PCR ve PLS kalibrasyonlarının kurulmasında faktör seçimi için çapraz validasyon işlemi kullanılmıştır. Bunun için karelerin tahmin hatalarının toplamı (prediction error sum of squares $\rightarrow$ PRESS) hesaplanmıştır. Optimal faktör sayısını bulmak için önerilen kriterler PRESS değeri ve F- istatistiğidir. Hesaplanan PRESS değerleri için aşağıda verilen formül kullanılmıştır [9-11]. 


$$
\text { PRESS }=\sum_{i=1}^{n}\left(C_{i}^{\text {eklenen }}-C_{i}^{\text {bulunan }}\right)^{2}
$$

Kemometrik kalibrasyonların validasyonu için kalibrasyonu ve tayin basamaklarında kalibrasyonun standart hatası (standard error of calibration $\rightarrow$ SEC) parametresi kullanılmaktadır. SEC değerini minimum yapan kalibrasyon koşulları ve F-istatistiği kullanılmaktadır. Çalışmada hesaplanan SEC değerleri için şu formül kullanılmıştır.

$$
\mathrm{SEC}=\sum_{\mathrm{i}=1}^{\mathrm{n}} \frac{\left(\mathrm{C}_{\mathrm{i}}^{\text {eklenen }}-\mathrm{C}_{\mathrm{i}}^{\text {bulunan }}\right)^{2}}{\mathrm{n}-1}
$$

PLS kalibrasyon yönteminde PLS 2 kullanılmıştır.

\section{Bulgular}

\subsection{UV/ VIS soğurma spektroskopisi analizleri}

Kemometrik yöntemlerin uygulanabilmesinde spektral koşullar optimizasyonu ve optimal kalibrasyon setinin hazırlanması için ön çalışmalar yapılmıştır. Saptanan spektral koşullarda kalibrasyon setinin ve numunelerin 200-350 nm dalga boyu aralığında absorbsiyon spektrumları alınmıştır ve kemometrik kalibrasyonlar 210-290 nm dalga boyu bölgesindeki bütün absorbans değerlerinin vektörel ölçümleri kullanılarak elde edilmiştir. Kemometrik algoritmalarla hesaplanan PCA, PCR ve PLS kalibrasyonları yapay ve farmosötik numunenin analizine uygulanmıştır.

Hidroklorotiyazid (HCT) ve kinapril (KIN) etken maddelerinin stok çözeltilerinden yola çıkarak çeşitli derişimlerde yeni çözeltiler hazırlanmış ve bu çözeltiler kalibrasyon ve validasyon seti oluşturmada kullanılmıştır. HCT ve KIN etken maddelerinin sentetik karışımları hazırlanırken ACCUZIDE ${ }^{\circledR}$ FORT içerisinde bulunan etken maddenin miktarları da dikkate alınmıştır. Analiz esnasında oluşabilecek kalibrasyon hatalarını azaltmak ve daha doğru sonuçlar elde edebilmek için, kalibrasyon ve validasyon seti hazırlanırken kullanılan etken maddelerin derişimleri simetrik olarak alınmıştır.

Kalibrasyon setinde kinapril derişim aralığı 4-20 $\mu \mathrm{g} / \mathrm{ml}$ (ppm) arasında, hidroklorotiyazid derişim aralığı ise 5-25 $\mu \mathrm{g} / \mathrm{ml}$ (ppm) arasında seçilmiştir. Validasyon setinde kinapril derişim aralı̆̆ 2-10 $\mu \mathrm{g} / \mathrm{ml}$ (ppm) arasında, hidroklorotiyazid derişim aralığı ise 2,5-12,5 $\mu \mathrm{g} / \mathrm{ml}$ (ppm) arasında seçilmiştir. Kalibrasyon seti 15 farklı set ile, validasyon seti ise 10 farklı set ile hazırlanmıştır. Hazırlanan validasyon setinin iki boyutlu düzlemdeki grafiği çizilmiştir (Şekil 3).

Mobil faz içerisindeki 8 ppm KIN, 10 ppm HCT aktif bileşenlerinin ayrı ayrı UV absorpsiyon spektrumları ile 8 ppm KIN ve 10 ppm HCT ile hazırlanan karışımın UV absorpsiyon spektrumları okunmuştur (Şekil 4).

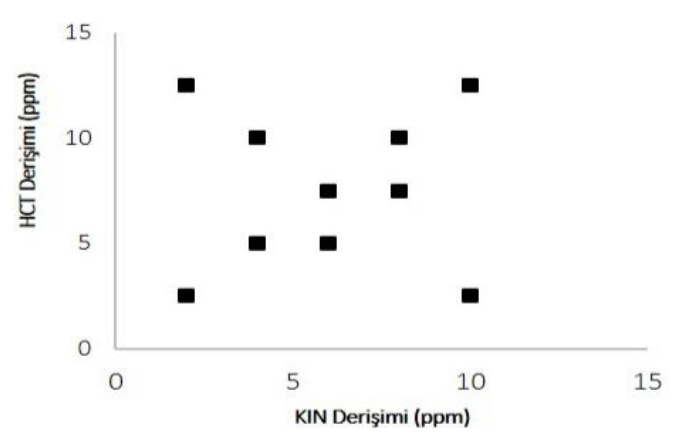

Şekil 3. Simetrik validasyon setinin iki boyutlu düzlemdeki grafiği

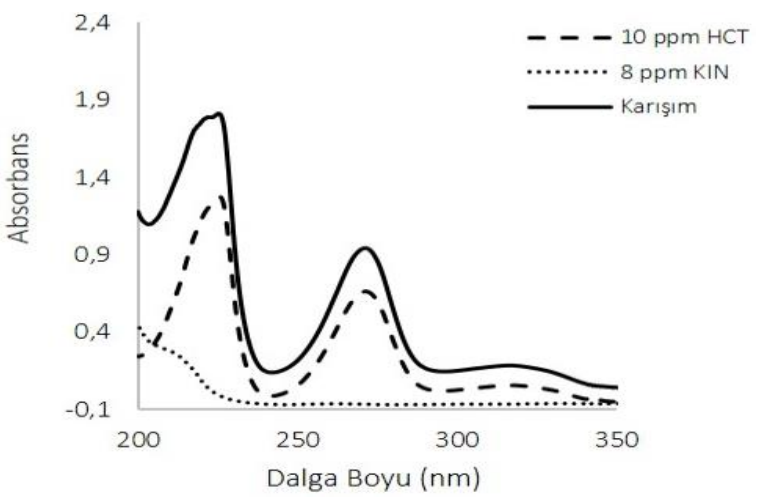

Şekil 4. Mobil faz içerisindeki 8 ppm KIN, 10 ppm HCT aktif bileșenlerinin ve karıșımlarının UV absorpsiyon spektrumları

Hazırlanan validasyon seti kullanılarak kurulan PLS ve PCR kalibrasyonun kesinliği ve doğruluğu test edilmiştir. PLS ve PCR sonuçları geri kazanımı ve standart sapması sırasıyla, kinapril için \% 99,18, 0,333 ve $\% 100,56,0,511$; hidroklorotiyazid için $\% 99,75,0,288$ ve $\% 99,85,0,026$ olarak bulunmuștur. PLS ve PCR kalibrasyon yönteminin sentetik karışımlara uygulanması ile elde edilen sonuçlar Çizelge 1 ve Çizelge 2'de gösterilmiștir.

Çizelge 1. Kinapril ve hidroklorotiyazid sentetik karışımlarına PLS kalibrasyon yönteminin uygulanması ve

\begin{tabular}{|c|c|c|c|c|c|}
\hline $\begin{array}{c}\text { Mix } \\
(\mathrm{ppm})\end{array}$ & $\begin{array}{c}\text { Bulunan } \\
\text { (ppm) }\end{array}$ & & $\begin{array}{c}\text { Mix } \\
(\mathrm{ppm})\end{array}$ & $\begin{array}{c}\text { Bulunan } \\
\text { (ppm) }\end{array}$ & \\
\hline KIN & KIN & $\begin{array}{c}\text { Geri } \\
\text { Kazanım } \\
(\%)\end{array}$ & HCT & HCT & $\begin{array}{c}\text { Geri } \\
\text { Kazanım } \\
(\%)\end{array}$ \\
\hline 2 & 1,985 & 99,250 & 2,5 & 2,490 & 99,600 \\
\hline 4 & 3,956 & 98,900 & 5 & 4,956 & 99,120 \\
\hline 6 & 5,968 & 99,466 & 7,5 & 7,489 & 99,853 \\
\hline 8 & 7,899 & 98,737 & 10 & 9,965 & 99,650 \\
\hline 10 & 9,965 & 99,650 & 12,5 & 12,498 & 99,984 \\
\hline 2 & 1,985 & 99,250 & 12,5 & 12,498 & 99,984 \\
\hline 4 & 3,981 & 99,525 & 10 & 9,950 & 99,500 \\
\hline 6 & 5,960 & 99,333 & 5 & 4,479 & 89,580 \\
\hline 8 & 7,925 & 99,062 & 7,5 & 7,499 & 99,986 \\
\hline \multirow[t]{3}{*}{10} & 9,867 & 98,670 & 2,5 & 2,498 & 99,920 \\
\hline & $\overline{\mathbf{x}}$ & 99,184 & & $\overline{\mathbf{x}}$ & 99,757 \\
\hline & SS & 0,333 & & SS & 0,288 \\
\hline
\end{tabular}
elde edilen geri kazanım değerleri 
Cizelge 2. Kinapril ve hidroklorotiyazid sentetik karışımlarına PCR kalibrasyon yönteminin uygulanması ve elde edilen geri kazanım değerleri

\begin{tabular}{cccccc}
\hline $\begin{array}{c}\text { Mix } \\
(\mathrm{ppm})\end{array}$ & $\begin{array}{c}\text { Bulunan } \\
(\mathrm{ppm})\end{array}$ & \multicolumn{5}{c}{$\begin{array}{c}\text { Mix } \\
(\mathrm{ppm})\end{array}$} & $\begin{array}{c}\text { Bulunan } \\
(\mathrm{ppm})\end{array}$ \\
\hline \multicolumn{5}{c}{ Geri } \\
KIN & KIN & $\begin{array}{c}\text { Kazanım } \\
\mathbf{( \% )}\end{array}$ & $\mathbf{H C T}$ & $\mathbf{H C T}$ & $\begin{array}{c}\text { Keri } \\
\text { Kazanim }\end{array}$ \\
2 & 2,009 & 100,497 & 2,5 & 2,495 & 99,831 \\
4 & 4,017 & 100,436 & 5 & 4,992 & 99,850 \\
6 & 6,024 & 100,413 & 7,5 & 7,489 & 99,861 \\
8 & 8,033 & 100,413 & 10 & 9,986 & 99,862 \\
10 & 10,041 & 100,411 & 12,5 & 12,482 & 99,860 \\
2 & 2,038 & 101,929 & 12,5 & 12,484 & 99,877 \\
4 & 4,032 & 100,806 & 10 & 9,986 & 99,867 \\
6 & 6,017 & 100,29 & 5 & 4,992 & 99,851 \\
8 & 8,023 & 100,296 & 7,5 & 7,490 & 99,867 \\
10 & 10,011 & 100,117 & 2,5 & 2,494 & 99,783 \\
& $\overline{\mathbf{x}}$ & 100,561 & & $\overline{\mathbf{x}}$ & 99,851 \\
& $\mathbf{S S}$ & 0,511 & & SS & 0,026 \\
\hline
\end{tabular}

Kinapril ve hidroklorotiyazid etken bileşenlerini sentetik karışımlarda bu ilaç etken maddelerin miktar tayini için PLS ve PCR kalibrasyonun kurulması için çapraz validasyon işleminde tahmin edilen hataların karelerinin toplamının (Predicted Resudiual Error Some of Squares $\rightarrow$ PRESS) minimal değerleri elde edilmiștir. Kurulan PLS ve PCR kalibrasyonunda PRESS değeri sırasıyla kinapril için $4,01 \times 10^{-2}$ ve $7,34 \times 10^{-3}$; hidroklorotiyazid için $2,7 \times 10^{-1}$ ve $1,26 \times 10^{-3}$ olarak hesaplanmıştır. PRESS değerinin sıfıra yakın olması doğruluk derecesini arttırmaktadır. Elde edilen PRESS değerleri yeterince küçüktür. Kalibrasyonun standart hatası (Standard error of calibration $\rightarrow$ SEC), gerçek ve tahmini derişimler arasındaki ilişkiye dayalı olarak hesaplanmıştır. Kurulan PLS ve PCR kalibrasyonunda SEC değeri sırasıyla kinapril için 0,063 ve 0,027 ; hidroklorotiyazid için 0,166 ve 0,009 olarak hesaplanmıştır. PLS ve PCR kalibrasyon yönteminin doğruluk ve kesinliğini valide etmek için elde edilen sonuçlara varyans testi (ANOVA) uygulanmıștır. ANOVA ile teorik olarak F-hesaplanan ve F-tablo değeri karşılaştırılmıştır. F-tablo değeri Fhesaplanandan büyük olma koşulu ve pearson korelasyon katsayısının (P) 0,05 değerine eşit veya büyük olması durumu desteklenmiştir

Kısmi en küçük kareler yöntemi (PLS) için gruplar arası serbestlik derecesi 1, gruplar içi serbestlik derecesi 18'dir. F-tablo değeri 4,41 olarak hesaplanmıştır. Kinapril F-hesaplanan 0,0014, pdeğeri 0,96; hidroklorotiyazid için F-hesaplanan 0,0016, p-değeri 0,96 olarak hesaplanmıştır. Temel bileşen regresyonu (PCR) için gruplar arası serbestlik derecesi 1 , gruplar içi serbestlik derecesi $18^{\prime}$ dir. Ftablo değeri 4,41 olarak hesaplanmıştır. Kinapril Fhesaplanan 0,00035, p-değeri 0,98; hidroklorotiyazid için F-hesaplanan 0,00004, p-değeri 0,96 olarak hesaplanmıştır. Her iki yöntemde de hesaplanan $\mathrm{F}$ değerleri, F-tablo değerlerinden küçük, pearson korelasyon katsayısı değerleri ise 0,05 değerinden büyüktür. Bu değerler PLS ve PCR yöntemlerinin numune analizinde kullanılmasının uygun olduğunu göstermektedir. Yapılan ANOVA testleri sonucunda ticari ilaç numunesine uygulanan PLS ve PCR kalibrasyon yöntemlerine ait veriler Çizelge 3'te verilmiştir.

Çizelge 3. Ticari ilaç numunesine PLS ve PCR kalibrasyon yönteminin uygulanmasıyla elde edilen sonuçlar

\begin{tabular}{cccccc}
\multicolumn{5}{c}{ HCT } & \multicolumn{5}{c}{ KIN } \\
$\begin{array}{c}\text { Deney } \\
\text { No }\end{array}$ & PLS & PCR & $\begin{array}{c}\text { Deney } \\
\text { No }\end{array}$ & PLS & PCR \\
$\mathbf{1}$ & 25,118 & 25,600 & $\mathbf{1}$ & 20,025 & 19,980 \\
$\mathbf{2}$ & 25,072 & 25,840 & $\mathbf{2}$ & 20,180 & 20,000 \\
$\mathbf{3}$ & 24,780 & 25,000 & $\mathbf{3}$ & 19,990 & 20,020 \\
$\mathbf{4}$ & 25,009 & 25,000 & $\mathbf{4}$ & 20,007 & 20,617 \\
$\mathbf{5}$ & 25,140 & 25,005 & $\mathbf{5}$ & 20,315 & 19,920 \\
$\mathbf{6}$ & 25,117 & 24,740 & $\mathbf{6}$ & 20,625 & 20,000 \\
$\overline{\mathbf{x}}$ & 25,039 & 25,031 & $\overline{\mathbf{x}}$ & 20,190 & 20,089 \\
$\mathbf{S S}$ & 0,135 & 0,299 & $\mathbf{S S}$ & 0,247 & 0,260 \\
$\mathbf{B S S}$ & 0,005 & 0,011 & $\mathbf{B S S}$ & 0,012 & 0,013 \\
\hline
\end{tabular}

* Elde edilen sonuçlar altı deneyin sonuçlarının ortalamasıdır.

\subsection{Yüksek performanslı sıvı kromatografisi (HPLC) analizleri}

Kinaprilin 4,8,12,16 ve 20 ppm olmak üzere beş farklı derişimde çözeltisi hazırlanmıştır. Kalibrasyon doğrusu, kinaprilin her bir derişim değeri için elde edilen pik alanının iç standart (donepezil) pik alanına oranının (KIN/IS), kinapril derişim değerine karşı işaretlenmesi ile oluşturulan grafiktir. Geliştirilen yöntem kinapril için 4-20 ppm arasında doğrusaldır (Şekil 5).

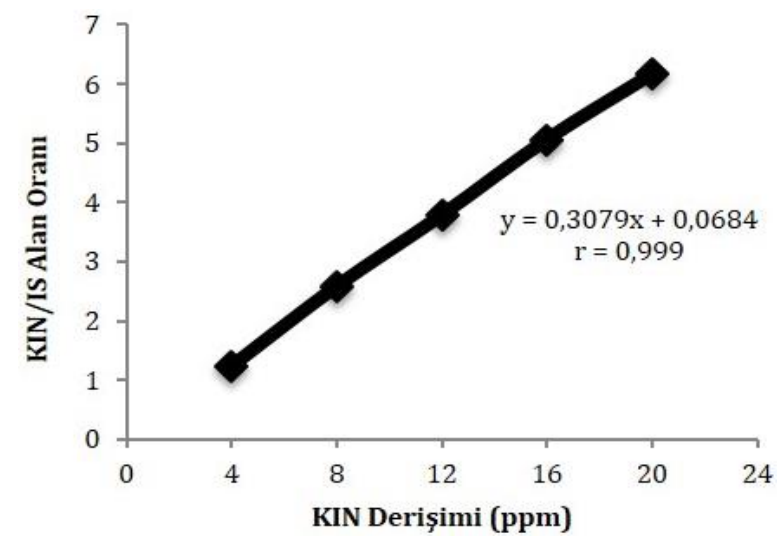

Şekil 5. KIN analizine ait doğrusal kalibrasyon grafiği

Hidroklorotiyazitin $5,10,15,20$ ve 25 ppm olmak üzere beş farklı derişimde çözeltisi hazırlanmıştır. Kalibrasyon doğrusu, hidroklorotiyazitin her bir derişim değeri için elde edilen pik alanının iç standart (donepezil) pik alanına oranının (HCT/IS), hidroklorotiyazid derişim değerine karşı işaretlenmesi ile oluşturulan grafiktir. Geliştirilen yöntem hidroklorotiyazitin için 5-25 ppm arasında doğrusaldır (Şekil 6). 


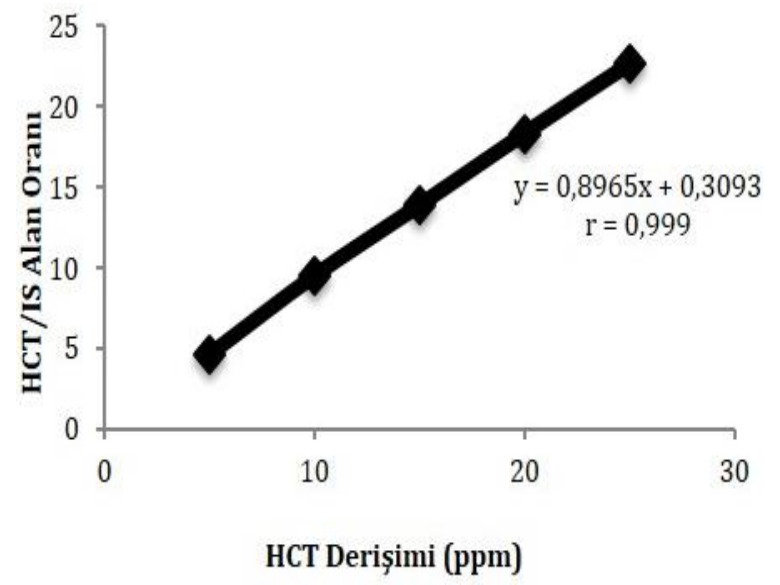

Şekil 6. HCT analizine ait doğrusal kalibrasyon grafiği

Yöntemin seçiciliğinin belirlenmesi amacıyla kalibrasyon doğrusu ve duyarlılığı verilerine göre teşhis sınırı değeri (LOD) tayin alt sınırı değeri (LOQ) hesaplanmıştır. LOD değeri LOQ değerinden küçük olmalıdır. Çizelge 4'de kalibrasyon fonksiyonları, bileşiklerin doğrusal olduğu aralıklar, LOD ve LOQ değerleri verilmiștir.

Çizelge 4. KIN ve HCT analizine ait doğrusal kalibrasyon grafik parametreleri

\begin{tabular}{lcc}
\hline & KIN & HCT \\
\hline Regrasyon Denklemi & $\mathrm{y}=0,3079 \mathrm{x}+$ & $\mathrm{y}=0,8965 \mathrm{x}+$ \\
& 0,0684 & 0,3093 \\
Denklemin standart & 0,073 & 0,193 \\
sapması & & \\
Kesimin standart sapması & 0,076 & 0,203 \\
Eğimin standart sapması & 0,006 & 0,012 \\
Kolerasyon katsayısı (r) & 0,999 & 0,999 \\
Kalibrasyon & & \\
Aralığı $(\mu \mathrm{g} / \mathrm{mL})$ & $4-20$ & $5-25$ \\
LOD $(\mu \mathrm{g} / \mathrm{mL})$ & 0,776 & 0,716 \\
LOQ $(\mu \mathrm{g} / \mathrm{mL})$ & 2,353 & 2,156 \\
\hline
\end{tabular}

Saf haldeki kinapril ve hidroklorotiyazid etken maddeleri için geliştirilen kromatografik yöntem, iki etken maddeyi de içeren ACCUZIDE ${ }^{\circledR}$ FORT tabletlerine de uygulanmıștır.

Hazırlanan çözeltilerin HPLC cihazında okunan kromatogramları yorumlanarak tablet içerisindeki kinapril ve hidroklorotiyazid miktarları hesaplanmıștır. Teorik ve deneysel derișim verileri kullanılarak \% geri kazanımlar elde edilmiştir (Çizelge 5 ve 6).
Çizelge 6. Tabletin katkılı ve katkısız olarak elde edilen kromatogram pik alan oran değerleri

\begin{tabular}{cccc}
\hline & Enjeksiyon & $\begin{array}{c}\text { Katkısız } \\
\text { Tablet }\end{array}$ & $\begin{array}{c}\text { Katkılı } \\
\text { Tablet }\end{array}$ \\
\hline $\begin{array}{c}\text { HCT/IS } \\
\text { alan } \\
\text { oranı }\end{array}$ & 1.Enjeksiyon & 7,0745 & 13,8568 \\
& 2.Enjeksiyon & 6,7421 & 13,8967 \\
& & 6,4517 & 13,9910 \\
KIN/IS & 1.Enjeksiyon & 2,7656 & 4,7347 \\
$\begin{array}{c}\text { alan } \\
\text { oranı }\end{array}$ & 2.Enjeksiyon & 2,5611 & 4,6940 \\
\hline
\end{tabular}

$210 \mathrm{~nm}$ dalga boyunda, tablet çözeltisinin analizini ve bileșiklere belirli derișimlerde katkı yapılan çözeltilerin analizini gösteren kromatogramlar Şekil 7'de yer almaktadır.
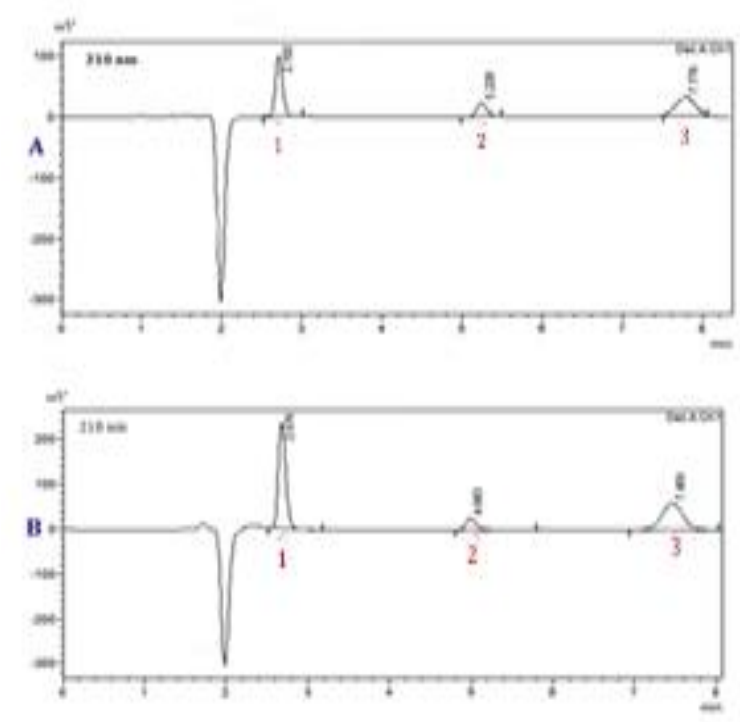

Şekil 7. A) 8 ppm KIN ve 10 ppm HCT içeren tablet çözeltisine ait kromatogram, $\quad$ B) 8 ppm KIN ve 10 ppm HCT içeren tablete aynı derişimde KIN ve HCT standardı ilave edilmiş çözeltiye ait kromatogram (1:HCT 2:IS 3:KIN)

Hidroklorotiyazid (HCT) ve kinapril (KIN) etken maddelerinin stok çözeltilerinden yola çıkarak çeşitli derişimlerde yeni çözeltiler hazırlanmış ve bu çözeltiler kalibrasyon seti oluşturmada kullanılmıştır. Analiz esnasında oluşabilecek kalibrasyon hatalarını azaltmak ve daha doğru sonuçlar elde edebilmek için, kalibrasyon seti hazırlanırken kullanılan etken maddelerin derişimleri simetrik olarak alınmıștır. Kalibrasyon setinde kinapril derișim aralığ 4 4-20 $\mu \mathrm{g} / \mathrm{ml}$ (ppm) arasında, hidroklorotiyazid derişim

Çizelge 5. HCT ve KIN içeren tabletlerin geri kazanım sonuçları

\begin{tabular}{ccccc} 
Numune no & $\begin{array}{c}\text { Tablette Bulunan } \\
\text { Hidroklorotiyazid miktarı (mg) }\end{array}$ & $\begin{array}{c}\text { Tablette Bulunan } \\
\text { Kinapril miktarı (mg) }\end{array}$ & $\begin{array}{c}\text { HCT } \\
\text { \% geri kazanım }\end{array}$ & $\begin{array}{c}\text { Kinapril } \\
\text { \% geri kazanım }\end{array}$ \\
\hline 1 & 25,256 & 19,411 & 101,025 & 97,056 \\
2 & 25,250 & 19,497 & 101,001 & 97,487 \\
3 & 25,136 & 19,668 & 100,546 & 98,344 \\
Xort \pm t.S $/ \sqrt{ }$ N & $25,214 \pm 0,167$ & $19,526 \pm 0,325$ & $100,857 \pm 0,670$ & $97,629 \pm 1,627$ \\
SS & 0,067 & 0,131 & 0,270 & 0,655 \\
\% BSS & 0,267 & 0,672 & 0,267 & 0,672 \\
\%Hata & $-0,857$ & 2,370 & $-0,857$ & 2,370 \\
\hline
\end{tabular}


aralığı ise $5-25 \mu \mathrm{g} / \mathrm{ml}(\mathrm{ppm})$ arasında seçilmiştir. İç standardın (donepezil) derişimi daima $2 \mu \mathrm{g} / \mathrm{ml}$ (ppm) olarak alınmıştır. Toplamda 5 farklı set hazırlanmış ve hepsinin HPLC sisteminde kromatogramları okunarak alan oranları alınmıştır.

İki etken maddenin (kinapril ve hidroklorotiyazid) ve iç standardın (donepezil) üçlü karışımı hazırlanmış ve bu karışımın HPLC' de en yüksek absorbans veren altı farklı dalga boyunda $(210,215,220,225,230$ ve $235 \mathrm{~nm}$ ) kromatogramı alınmıştır.

KIN ve HCT stok çözeltilerinden yola çıarak validasyon seti hazırlanmıştır ve iki boyutlu düzlemdeki grafiği çizilmiştir (Şekil 8). Hazırlanan validasyon seti kullanılarak kurulan PLS ve PCR kalibrasyonun kesinliği ve doğruluğu test edilmiştir. PLS ve PCR sonuçları geri kazanım ve standart sapma sırasıyla, kinapril için \% 100,57, 0,461 ve \% 100,008, 0,169 ; hidroklorotiyazid için \%100,52 0,706 ve \%99,78, 0,241 olarak bulunmuştur. PLS kalibrasyon yönteminin sentetik karışımlara uygulanması ile elde edilen sonuçlar Çizelge 7 ve Çizelge 8'de gösterilmiștir.

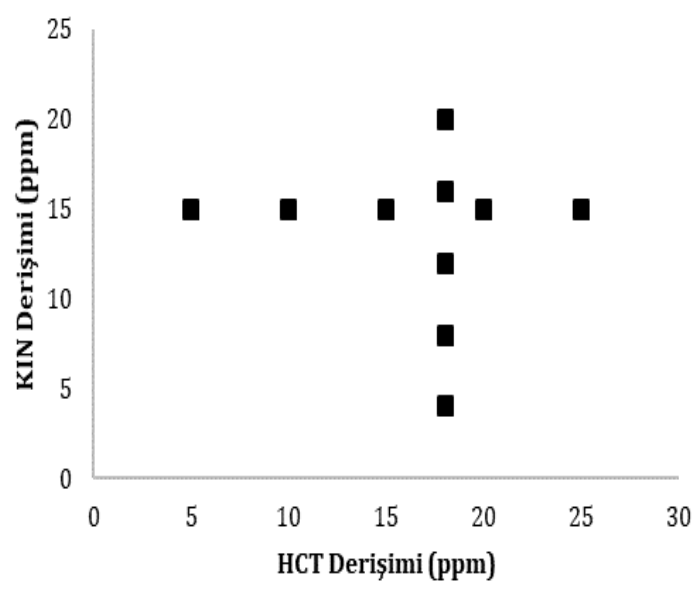

Şekil 8. Kinapril ve hidroklorotiyazid analizi için iki boyutlu düzlemdeki validasyon grafiği

Çizelge 7. KIN ve HCT sentetik karışımlarına PCR kalibrasyon yönteminin uygulanması ve elde edilen geri kazanım değerleri

\begin{tabular}{cccccc}
\hline $\begin{array}{c}\text { Mix } \\
(\mathrm{ppm})\end{array}$ & $\begin{array}{c}\text { Bulunan } \\
(\mathrm{ppm})\end{array}$ & \multicolumn{5}{c}{$\begin{array}{c}\text { Mix } \\
(\mathrm{ppm})\end{array}$} & $\begin{array}{c}\text { Bulunan } \\
(\mathrm{ppm})\end{array}$ \\
\hline KIN & KIN & $\begin{array}{c}\text { Geri } \\
\text { KazanIm } \\
\mathbf{( \% )}\end{array}$ & $\mathbf{H C T}$ & $\mathbf{H C T}$ & $\begin{array}{c}\text { Geri } \\
\text { Kazanim } \\
\mathbf{( \% )}\end{array}$ \\
15 & 15,001 & 100,010 & 5 & 4,981 & 99,638 \\
15 & 14,995 & 99,970 & 10 & 9,957 & 99,574 \\
15 & 14,991 & 99,943 & 15 & 14,963 & 99,755 \\
15 & 14,998 & 99,991 & 20 & 19,968 & 99,840 \\
15 & 15,007 & 100,047 & 25 & 24,975 & 99,902 \\
4 & 4,017 & 100,445 & 18 & 17,939 & 99,664 \\
8 & 8,004 & 100,054 & 18 & 17,912 & 99,512 \\
12 & 11,985 & 99,879 & 18 & 17,925 & 99,588 \\
16 & 15,973 & 99,832 & 18 & 18,016 & 100,091 \\
20 & 19,981 & 99,904 & 18 & 18,045 & 100,253 \\
& $\overline{\mathbf{x}}$ & 100,008 & & $\overline{\mathbf{x}}$ & 99,782 \\
& $\mathbf{S S}$ & 0,169 & & $\mathbf{S S}$ & 0,241 \\
\hline
\end{tabular}

Çizelge 8. KIN ve HCT sentetik karışımlarına PLS kalibrasyon yönteminin uygulanması ve elde edilen geri kazanım değerleri

\begin{tabular}{cccccc}
\hline $\begin{array}{c}\text { Mix } \\
(\mathrm{ppm})\end{array}$ & $\begin{array}{c}\text { Bulunan } \\
(\mathrm{ppm})\end{array}$ & \multicolumn{5}{c}{$\begin{array}{c}\text { Mix } \\
(\mathrm{ppm})\end{array}$} & $\begin{array}{c}\text { Bulunan } \\
(\mathrm{ppm})\end{array}$ \\
\hline KIN & KIN & $\begin{array}{c}\text { Geri } \\
\text { Kazanım } \\
\mathbf{( \% )}\end{array}$ & HCT & HCT & $\begin{array}{c}\text { Geri } \\
\text { Kazanım } \\
\mathbf{( \% )}\end{array}$ \\
15 & 15,065 & 100,433 & 5 & 5,001 & 100,020 \\
15 & 15,032 & 100,213 & 10 & 10,026 & 100,265 \\
15 & 15,152 & 101,013 & 15 & 15,369 & 102,460 \\
15 & 15,102 & 100,680 & 20 & 20,036 & 100,180 \\
15 & 15,087 & 100,580 & 25 & 25,098 & 100,392 \\
4 & 4,015 & 100,375 & 18 & 18,074 & 100,411 \\
8 & 8,129 & 101,612 & 18 & 18,125 & 100,694 \\
12 & 12,028 & 100,233 & 18 & 18,032 & 100,177 \\
16 & 16,096 & 100,600 & 18 & 18,045 & 100,250 \\
20 & 20,000 & 100,000 & 18 & 18,056 & 100,311 \\
& $\overline{\mathbf{x}}$ & 100,574 & & $\overline{\mathbf{x}}$ & 100,516 \\
& $\mathbf{S S}$ & 0,461 & & $\mathbf{S S}$ & 0,706 \\
\hline
\end{tabular}

Kinapril ve hidroklorotiyazid etken bileşenlerini sentetik karıșımlarda bu ilaç etken maddelerin miktar tayini için PLS ve PCR kalibrasyonun kurulması için çapraz validasyon işleminde tahmin edilen hataların karelerinin toplamının (Predicted Resudiual Error Some of Squares $\rightarrow$ PRESS) minimal değerleri elde edilmiştir. Kurulan PLS ve PCR kalibrasyonunda PRESS değeri sırasıyla kinapril için $7,3 \times 10^{-2}$ ve $1,7 \times 10^{-3}$; hidroklorotiyazid için $1,7 \times 10^{-1}$ ve $2,4 \times 10^{-2}$ olarak hesaplanmıștır. PRESS değerinin sıfıra yakın olması doğruluk derecesini arttırmaktadır. Elde edilen PRESS değerleri yeterince küçüktür. Kalibrasyonun standart hatası (Standard error of calibration $\rightarrow$ SEC), gerçek ve tahmini derişimler arasındaki ilişkiye dayalı olarak hesaplanmıștır. Kurulan PLS ve PCR kalibrasyonunda SEC değeri sırasıyla kinapril için 0,069 ve 0,010; hidroklorotiyazid için 0,108 ve 0,041 olarak hesaplanmıştır. PLS ve PCR kalibrasyon yönteminin doğruluk ve kesinliğini valide etmek için elde edilen sonuçlara varyans testi (ANOVA) uygulanmıştır. ANOVA ile teorik olarak F-hesaplanan ve F-tablo değeri karşılaştırılmıştır. F-tablo değeri Fhesaplanandan büyük olma koşulu ve pearson korelasyon katsayısının (P) 0,05 değerine eşit veya büyük olması durumu desteklenmiștir.

Kısmi en küçük kareler yöntemi (PLS) için gruplar arası serbestlik derecesi 1, gruplar içi serbestlik derecesi 18'dir. F-tablo değeri 4,41 olarak hesaplanmıştır. Kinapril F-hesaplanan 0,00128, pdeğeri 0,97; hidroklorotiyazid için F-hesaplanan 0,00123, p-değeri 0,97 olarak hesaplanmıștır. Temel bileşen regresyonu (PCR) için gruplar arası serbestlik derecesi 1, gruplar içi serbestlik derecesi 18'dir. Ftablo değeri 4,41 olarak hesaplanmıștır. Kinapril Fhesaplanan 0,00004, p-değeri 0,99; hidroklorotiyazid için F-hesaplanan 0,00016, p-değeri 0,98 olarak hesaplanmiștır. Her iki yöntemde de hesaplanan $\mathrm{F}$ değerleri, F-tablo değerlerinden küçük, pearson korelasyon katsayısı değerleri ide 0,05 değerinden büyüktür. $\mathrm{Bu}$ değerler PLS ve PCR yöntemlerinin 
numune analizinde kullanılmasının uygun olduğunu göstermektedir.

PLS ve PCR yönteminin HCT ve KIN etken maddelerini bulunduran ilaç numunesi kullanılarak tablet çözeltisi hazırlanmıştır. Hazırlanan çözelti 210$235 \mathrm{~nm}$ dalga boyu aralığında HPLC ile ölçülen absorbans değerlerine, PCR ve PLS algoritması uygulanmıştır ve tablet içeriğinde bulunan HCT ve KIN hesaplanmıştır. Bu işlem için altı tekrar yapılmıştır. Elde edilen veriler altı deneyin ortalaması olarak, Çizelge 9'da verilmiştir.

Çizelge 9. Ticari ilaç numunesine PCR ve PLS yöntemlerinin uygulanması sonucunda elde edilen HCT ve KIN değerleri (mg/tablet)

\begin{tabular}{cccccc}
\hline \multicolumn{3}{c}{ HCT } & \multicolumn{3}{c}{ KIN } \\
\hline Deney No & PLS & PCR & Deney No & PLS & PCR \\
$\mathbf{1}$ & 25,380 & 25,421 & $\mathbf{1}$ & 20,304 & 20,299 \\
$\mathbf{2}$ & 25,281 & 25,326 & $\mathbf{2}$ & 20,225 & 20,220 \\
$\mathbf{3}$ & 24,391 & 24,429 & $\mathbf{3}$ & 19,513 & 19,509 \\
$\mathbf{4}$ & 24,678 & 24,713 & $\mathbf{4}$ & 19,742 & 19,735 \\
$\mathbf{5}$ & 25,007 & 25,042 & $\mathbf{5}$ & 20,006 & 19,998 \\
$\mathbf{6}$ & 25,287 & 25,322 & $\mathbf{6}$ & 20,229 & 20,222 \\
$\overline{\mathbf{x}}$ & 24,991 & 25,041 & $\overline{\mathbf{x}}$ & 19,992 & 19,997 \\
SS & 0,304 & 0,395 & SS & 0,199 & 0,315 \\
BSS & 0,012 & 0,015 & $\mathbf{B S S}$ & 0,009 & 0,016 \\
\hline
\end{tabular}

* Elde edilen sonuçlar altı deneyin sonuçlarının ortalamasıdır.

\section{Tartıșma ve Sonuç}

$\mathrm{Bu}$ çalışmada, hipertansiyon (yüksek tansiyon) hastalığında kullanılan ACCUZIDE ${ }^{\circledR}$ FORT adlı ilaç ve içeriğindeki etken maddeler (KIN ve HCT) çeşitli spektroskopik ve kromatografik yöntemlerle incelenmiş ve kemometrik yöntemlerle istatistiksel olarak değerlendirilmiștir.

İlaç içinde bulunan kinapril ve hidroklorotiyazid etken maddeleri önce mor ötesi ve görünür bölge (UV/ VIS) soğurma spektroskopisi ile, daha sonra yüksek performanslı sıvı kromatografisi (HPLC) ile analiz edilmiş ve bu analiz sonuçları kemometrik yöntemlerle (PLS ve PCR) ayrı ayrı yorumlanmıştır.

Her iki yöntemde çizilen kalibrasyon grafiklerine bakıldığında regresyon değerinin $\left(\mathrm{R}^{2}\right), 1^{\prime}$ e çok yakın olduğu görülmüştür. Hesaplanan geri kazanım verilerinin ise oldukça yüksek olduğu görülmüştür. Ayrıca UV/VIS ve HPLC analiz sonuçları da birbiriyle kıyaslanmıştır.

Kemometrik veriler işlenirken F-testinden yararlanılmıștır. İstatistiksel anlamda yapılan değerlendirmede F-hesaplanan değeri F-tablo değerinden daima büyük çıkmıştır. Pearson korelasyon katsayısının (P) ise tüm çalışmalarda 0,05'den büyük çlkarak \%95 güven aralığını vermiştir.

$\mathrm{Bu}$ çalışmayı literatür çalışmalarından ayıran temel özelliği, UV/VIS ve HPLC ile yapılan analiz sonuçlarının birbiriyle kıyaslanmasının yanında istatistiksel yöntemlerle değerlendirilmesi olmuştur. Geliştirilen kemometrik yöntemlerin (PCA, PCR, PLS), yüksek duyarlılık ve tekrarlanabilir sonuçlar vermesi, geçerli, duyarlı, seçici, hızlı ve ekonomik olması bu yöntemlerin kinapril ve hidroklorotiyazid içeren hipertansiyon ilaçlarında kullanılabilir olduğunu göstermiştir.

\section{Teşekkür}

5099-YL1-17 No'lu proje ile bu çalıșmayı destekleyen Süleyman Demirel Üniversitesi Bilimsel Araştırma Projeleri Yönetim Birimi Başkanlığına teşekkür ederiz.

\section{Kaynakça}

[1] Dökmeci, İ., Dökmeci, H., 2006. Farmakoloji. İstanbul Medikal Yayıncılık, 271s, İstanbul.

[2] Üresin, Y. ed. 2004. ACE İnhibitörleri. Avrupa Tıp, İstanbul, 184s.

[3] Önder, R., Özerkan Çakan, F., 2012. Hipertansiyon. Ege Üniversitesi Yayınları, 78s, İzmir.

[4] Strube, G., Strube, G., 1992. ACE Inhibitors in Hypertension: A Guide for General Practitioners. Springer Netherlands, Dordrecht, 104s.

[5] https://pubchem.ncbi.nlm.nih.gov (Erişim Tarihi: 21.02.2019).

[6] Gawande, V.T., Miniyar, P.B., Bhandari, D.D., Ghag, M.K., Rajput D.B., Mahajan, A.A., 2014. Simultaneous Estimation of Quinapril Hydrochloride and Hydrochlorothiazide from Pharmaceutical Formulation by Using UV, IR and RP-HPLC. Asian Journal of Chemistry, 26 (13), 3799-3804.

[7] Gandhımathı, M., Ravi, T. K., 2009. Ion Pair-HPLC Method for the Simultaneous Estimation of Quinapril and Hydrochlorothiazide in Tablets. Indian Journal of Pharmaceutical Sciences, 71 (3), 311-313.

[8] Altunsoy, S., Bozal-Palabıyık, B., Uslu, B., 2013. Valıdation of Liquid Chromatographic Method for Simultaneous Determination of Quinapril and Hydrochlorothiazıde in Pharmaceutical Dosage Forms. Turkish Journal of Pharmaceutical Sciences, 10 (2013), 255-262.

[9] Dinç, E., 2007. Kemometri Çok Değişkenli Kalibrasyon Yöntemleri. Hacettepe Üniversitesi Eczacılık Fakültesi Dergisi, 27 (1), 61-92.

[10] Gündüz, T., 1998. Kimyacılar İçin İstatistik, Gazi Büro Kitapevi, Ankara, 230s.

[11] Otto, M., 2016. Chemometrics: Statistics and Computer Application in Analytical Chemistry. John Wiley \& Sons, New York, 400p. 
A. H. Aktaş, U. Yavaş / Yüksek Tansiyon Tedavisinde Kullanılan Bazı İlaç Etken Maddelerinin UV/VIS Spektrofotometrik ve Yüksek Basınçlı Sıvı Kromatog rafik (HPLC) Yöntemlerle İncelenmesi ve Elde Edilen Verilerin Kemometrik Yöntemlerle Değerlendirilmesi

\section{Ekler}

Ek A. Çizelge 10 ve Şekil 9-10.

Çizelge 10. HPLC konsantrasyon setleri ve etken maddelerin iç standarta karşı alan oranları

\begin{tabular}{|c|c|c|c|c|c|c|c|c|c|c|c|c|c|c|c|}
\hline \multirow[b]{2}{*}{ Mix } & \multicolumn{3}{|c|}{$\begin{array}{l}\text { Konsantrasyon } \\
\text { seti }(\mu \mathrm{g} / \mathrm{mL})\end{array}$} & \multicolumn{6}{|c|}{ Pik alanları oranı (HCT/IS) } & \multicolumn{6}{|c|}{ Pik alanları oranı (HCT/IS) } \\
\hline & HCT & KIN & IS & $\begin{array}{l}210 \\
\text { (A) }\end{array}$ & $\begin{array}{l}215 \\
\text { (B) }\end{array}$ & $\begin{array}{l}220 \\
(\mathrm{C})\end{array}$ & $\begin{array}{l}225 \\
\text { (D) }\end{array}$ & $\begin{array}{r}230 \\
(\mathrm{E})\end{array}$ & $\begin{array}{c}235 \\
(F)\end{array}$ & $\begin{array}{l}210 \\
\text { (A) }\end{array}$ & $\begin{array}{l}215 \\
\text { (B) }\end{array}$ & $\begin{array}{l}220 \\
(C)\end{array}$ & $\begin{array}{l}225 \\
\text { (D) }\end{array}$ & $\begin{array}{c}230 \\
(\mathrm{E})\end{array}$ & $\begin{array}{c}235 \\
(F)\end{array}$ \\
\hline 1 & 5 & 4 & 2 & 2,1952 & 3,9894 & 7,9657 & 8,1532 & 5,2332 & 2,4763 & 1,2529 & 1,2912 & 1,3033 & 0,6927 & 0,3004 & 0,2033 \\
\hline 2 & 10 & 8 & 2 & 4,5485 & 8,2427 & 14,5774 & 16,6617 & 10,2146 & 4,5286 & 2,6692 & 2,7515 & 2,4506 & 1,4472 & 0,5641 & 0,3311 \\
\hline 3 & 15 & 12 & 2 & 6,5143 & 11,7547 & 20,9032 & 23,9204 & 14,3138 & 6,3233 & 3,7775 & 3,8706 & 3,5165 & 2,0546 & 0,7898 & 0,4652 \\
\hline 4 & 20 & 16 & 2 & 8,7321 & 15,8688 & 28,8732 & 32,4562 & 19,2418 & 8,4088 & 5,1027 & 5,2536 & 4,8696 & 2,7977 & 1,0696 & 0,6188 \\
\hline 5 & 25 & 20 & 2 & 10,7862 & 19,3910 & 35,1828 & 38,3658 & 24,2071 & 10,6520 & 6,1133 & 6,2607 & 5,7396 & 3,2580 & 1,3613 & 0,8033 \\
\hline
\end{tabular}

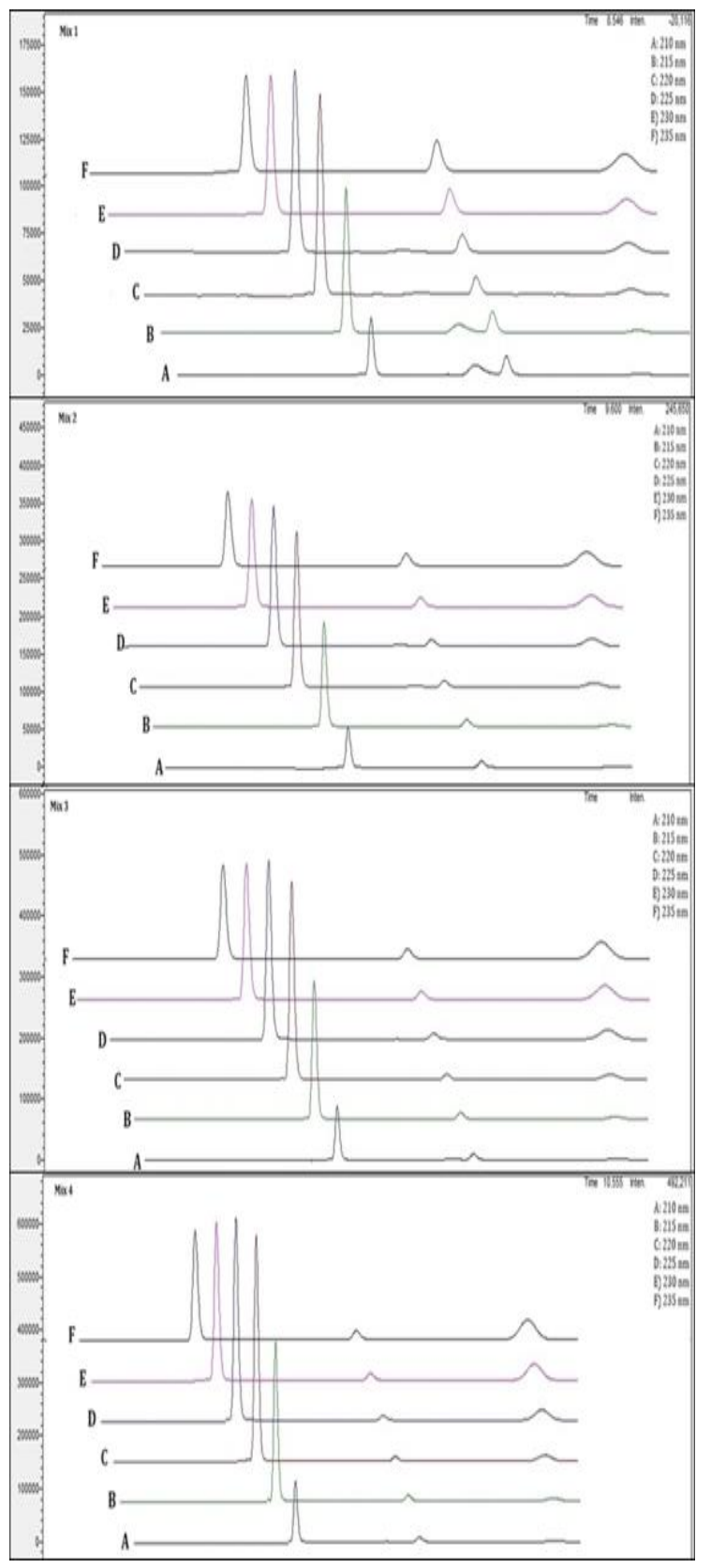

Şekil 9. 1-4 No'lu karışım setlerinin HPLC kromatogramları 


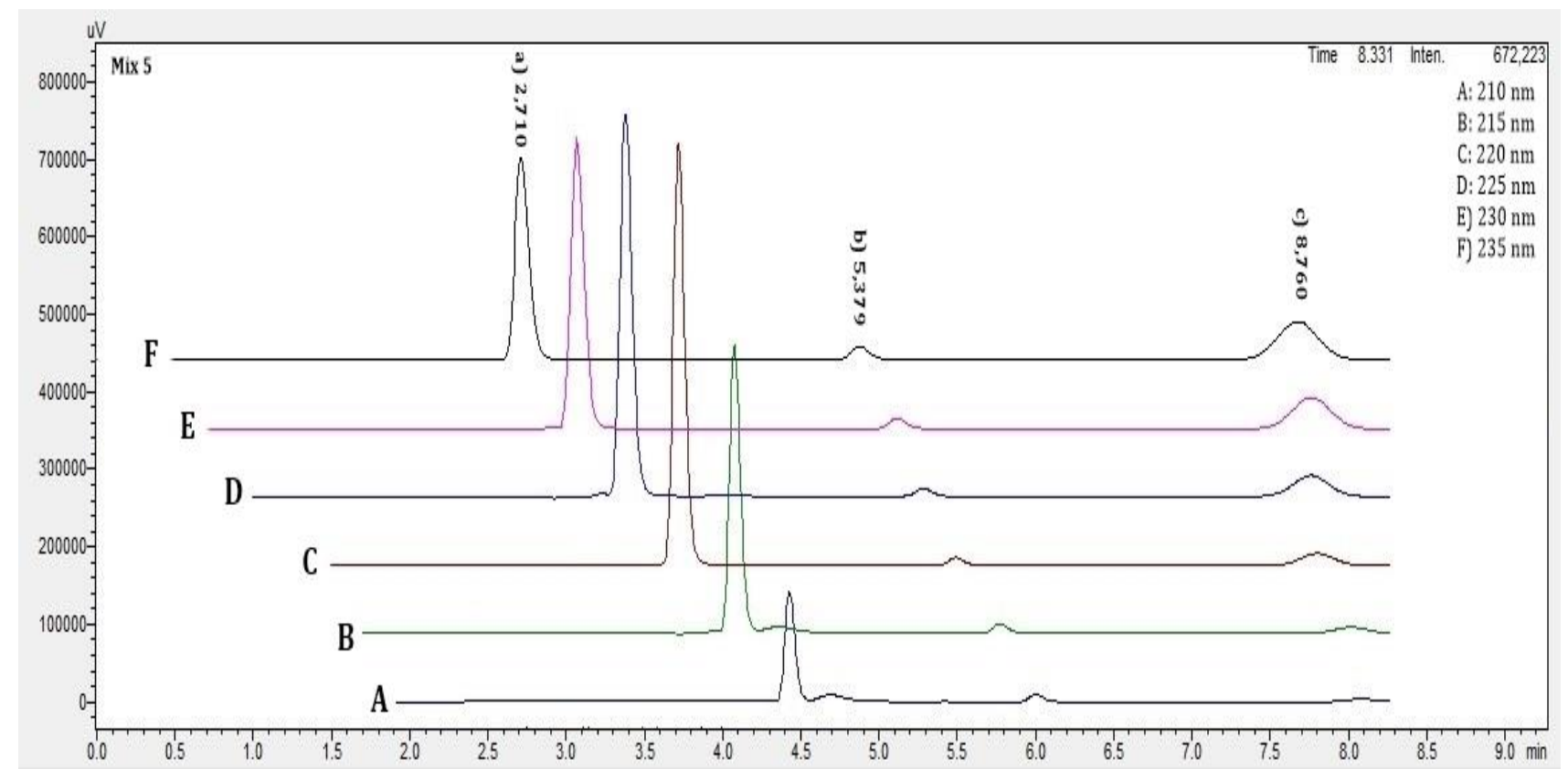

Şekil 10. 5 No'lu karışım setinin HPLC kromatogramı a) $25 \mu \mathrm{g} / \mathrm{mL}$ HCT b) $2 \mu \mathrm{g} / \mathrm{mL}$ DON c) $20 \mu \mathrm{g} / \mathrm{mL}$ 